\title{
Septoria leaf spot in organic tomatoes under diverse irrigation systems and water management strategies
}

\author{
Ricardo N Cabral'; Waldir A Marouelli²; Daniel AC Lage ${ }^{1}$; Adalberto C Café-Filho ${ }^{1}$ \\ ${ }_{1}^{1}$ Universidade de Brasilia, Depto. Fitopatologia, Campus Darcy Ribeiro, 70910-900 Brasília-DF; ricardoct5@gmail.com; \\ danielcostalage@gmail.com; cafefilh@unb.br (autor para correspondencia); ${ }^{2}$ Embrapa Hortaliças, C. Postal 218, 70351-970 Brasília-DF; \\ waldir.marouelli@embrapa.br
}

\begin{abstract}
The objective of this study was to analyze the temporal progress of septoria leaf spot of tomato, caused by Septoria lycopersici, in different irrigation systems. The experiment was carried out in an organic farming system, in a randomized block design with three replicates. Six irrigation systems were evaluated: $\mathrm{GO}_{1 \mathrm{~L}}$ : one dripline per row of plants; $\mathrm{GO}_{2 \mathrm{~L}}$ : two drip-lines; $\mathrm{SU}$ : furrow; $\mathrm{MI}_{\text {sub }}$ : microsprinkler below plant canopy; $\mathrm{MI}_{\text {alta }}$ : microsprinkler above plant canopy; AS: overhead sprinkler irrigation. Water management strategies varied with soil moisture tensions. Irrigation by drip systems was carried out when soil water tensions reached $15-30 \mathrm{kPa}$ (high moisture), whereas for SU the trigger soil tension was 30-60 $\mathrm{kPa}$ (moderate moisture). All other systems were conducted at both soil water tension ranges. One additional treatment was conducted with overhead sprinkler, high soil moisture and straw mulch ( $\left.\mathrm{AS}_{\text {palha }}\right)$. The disease manifested itself by natural infection, and quantification was carried out weekly from the onset of symptoms. Disease severity was estimated at the halfway point $\left(\mathrm{Y}_{50}\right)$ and at the end $\left(\mathrm{Y}_{\max }\right)$ of the time-course of the epidemics, and the area under the disease progress curve was also calculated (AUDPC). Disease progress analysis was done after fitting severity data to the Gompertz model. Highest $Y_{\max }(30-35 \%)$ values were found in the AS systems, while the lowest severities were associated with MI (6-10\%), GO and SU (4\%), indicating that the smaller the water drop size, the lower the disease severity. To a lesser extent, higher frequencies of irrigation in the AS and MI systems also favored higher disease levels. The use of straw mulch $\left(\mathrm{AS}_{\text {palha }}\right)$ significantly reduced $\mathrm{Y}_{50}$ and AUDPC, when compared to AS.
\end{abstract}

Keywords: Solanum lycopersicum, Septoria lycopersici, organic agriculture, fresh-market tomato, epidemiology.

\section{RESUMO}

Septoriose em tomateiro orgânico em diferentes sistemas de irrigação e estratégias de manejo de água

O objetivo do trabalho foi avaliar o progresso temporal da septoriose, causada por Septoria lycopersici, em tomateiro orgânico em distintos sistemas e estratégias de manejo de irrigação, nas condições de inverno seco da Região Centro-Oeste. Avaliaram-se seis configurações de sistemas de irrigação: gotejamento com uma $\left(\mathrm{GO}_{1 \mathrm{~L}}\right)$ e duas $\left(\mathrm{GO}_{2 \mathrm{~L}}\right)$ linhas por fileira de plantas; sulco (SU); microaspersão "subcopa" $\left(\mathrm{MI}_{\text {sub }}\right)$ e acima do dossel ( $\mathrm{MI}_{\text {alta }}$ ); e aspersão convencional (AS). As estratégias de manejo variaram em função da umidade do solo. Regas nos sistemas $\mathrm{GO}_{1 \mathrm{~L}}$ e $\mathrm{GO}_{2 \mathrm{~L}}$ foram realizadas quando a tensão de água no solo atingia 15-30 kPa (umidade elevada), enquanto para SU considerou-se a tensão-limite de $30-60 \mathrm{kPa}$ (umidade moderada). Os demais sistemas foram conduzidos nas duas faixas de tensão. Um tratamento adicional foi irrigado por aspersão, com umidade elevada e solo coberto por palhada $\left(\mathrm{AS}_{\text {palha }}\right.$ ). A doença manifestou-se por infecção natural e as avaliações foram semanais. Estimou-se a severidade na metade $\left(\mathrm{Y}_{50}\right)$ e no final $\left(\mathrm{Y}_{\max }\right)$ do curso temporal da epidemia e a área abaixo da curva de progresso da doença (AUDPC). Análise do progresso da doença foi feita ajustando-se os dados de severidade ao modelo de Gompertz. Maiores $\mathrm{Y}_{\max }$ ocorreram nos tratamentos irrigados por aspersão convencional (30-35\%), enquanto as menores severidades foram verificadas com microaspersão (6-10\%), gotejamento e sulco (4\%), indicando que quanto menor o tamanho das gotas de água aspergidas sobre o tomateiro menor é a severidade da doença. Embora em menor intensidade que o tamanho da gota de água, irrigações mais frequentes por aspersão convencional e microaspersão favoreceram a maior severidade da doença. O uso de palhada sobre o solo $\left(\mathrm{AS}_{\text {palha }}\right)$ reduziu $\mathrm{Y}_{50}$ e AUDPC em relação a AS.

Palavras-chave: Solanum lycopersicum, Septoria lycopersici, agricultura orgânica, tomate de mesa, epidemiologia.

(Recebido para publicação em 27 de novembro de 2012; aceito em 5 de julho de 2013)

(Received on November 27, 2012; accepted on July 5, 2013)

$\mathrm{T}^{\mathrm{s}}$ he market for organic products has been increasing significantly throughout the world, as demand grows for healthy foods free of chemical residues. Among organic fruits and vegetables, the tomato is one of the most sought-after, because the crop requires intensive use of pesticides when it is grown in conventional production systems. However, it is a huge challenge to grow tomato in organic systems because of the crop's high susceptibility to various pests and diseases (Souza, 2003; Schallenberger et al., 2008).

It is clear that management is fundamental to maintain an appropriate level of crop healthiness, and thus making sustainable production feasible. For this, the way that natural resources are used may affect tomato cultivation in a number of ways; this is particularly true of water, which is usually applied to the crop by irrigation (Marouelli et al., 2011b).

The conditions that favor most plant diseases are the presence of free water on the leaves and high water content in the soil (Rotem \& Palti, 1969; Lage et al., 2011b; Marouelli et al., 2005). Shortage, and especially excess of water, 
increases the incidence of various pests and diseases of tomato. In particular, the appearance and development of some diseases of tomato are connected to the form which water is applied to the plants (Marouelli et al., 2011b). Furrow and drip irrigation systems, which do not wet the aerial part of the plants, minimize the incidence of a number of diseases (Marouelli et al., 2005).

Among the diseases that attack the aerial part of tomato, septoria leaf spot, caused by Septoria lycopersici, is particularly severe in conditions of high humidity and mild temperatures (MacNeill, 1950), occurring in almost all productive regions of Brazil and the world (Jones et al., 1991; Kurozawa \& Pavan, 2005). The pathogen is seed-transmitted, but may also survive in crop debris (Lopes et al., 2005). Temperatures of $20-25^{\circ} \mathrm{C}$, high humidity and rain showers are the ideal conditions for the pathogen to spread and the disease to develop. When plants are infected under these conditions, the leaves, starting from the oldest ones, are severely attacked by the pathogen until the leaf area is completely destroyed (Elmer \& Ferrandino, 1995), reducing fruit yield greatly, not only because of the loss of photosynthetic area, but also because the fruit is exposed to sunburn.

The fungus is mainly a foliar pathogen; it can also attack the stalks, petioles and sepals (Lopes et al., 2005), but rarely the fruit. Disease symptoms are characterized by elliptical spots with dark edges and a grey center, with or without a chlorotic halo (MacNeill, 1950). In favorable conditions, it is possible to see black points that are made by fungal fructifications (pycnidia), in the center of the lesions. The conidia are released in the form of cirrus, gathered in a mucilaginous substance and spread mainly by water splashes (Lopes et al., 2005; Kurozawa \& Pavan, 2005).

The tomato plant's source of genetic resistance to $S$. lycopersici is quantitative and strongly influenced by environment. The current context is one of increased demand for fewer pesticide residues, even in conventionally grown crops (Lopes et al., 2005). Considering this, and due to the difficulty in obtaining genotypes that present good levels of resistance to the pathogen, the adoption of integrated management strategies to combat the disease has become of fundamental importance.

One of the most effective management strategies to hamper disease development is the appropriate type of irrigation (Rotem \& Palti, 1969; Lopes et al., 2006). The way in which water is applied to plants may, for example, alter the microclimate within the canopy of the crop, influencing the development and severity of diseases in that it may modulate survival, spread and infectivity of the pathogen (Lopes et al., 2006, Lage et al., 2011b). Although drip irrigation systems are considered most favorable in terms of providing higher productivity and fewer opportunities for pathogens of the aerial part, in Brazil the furrow system is still widely used in conventional production of staked tomatoes (Marouelli et al., 2011a). However, in contrast to the majority of conventional producers of staked tomatoes, sprinkler irrigation has been used by a number of organic tomato producers (Marouelli et al., 2011b). This takes place especially due to logistic and economic reasons as well as a way of controlling some insect pests and powdery mildew, caused by several members of the Erysiphaceae family (Marouelli et al., 2011b, Lage et al., 2011a).

The present work aimed to analyze the temporal progress of septoria leaf spot in organic tomato, using various management strategies and configurations of irrigation systems, in the edapho-climatic conditions found in winter in central Brazil.

\section{MATERIAL AND METHODS}

The experiment was carried out in the Organic Vegetable Research and Production Area of Embrapa Hortaliças,

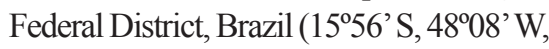
altitude $997 \mathrm{~m}$ ), from May to October 2011. The experimental area is within a few hundred meters of fields that have been planted with tomato for many years. The soil of the experimental area is classified as typical dystrophic red latosol, Cerrado phase, with clay texture and water retention capacity of $1.2 \mathrm{~mm} / \mathrm{cm}$. The climate of the region is type Cwa, humid temperate with a dry winter and a hot summer, according to the Köppen-Geiger classification.

Six different irrigation systems were evaluated: one drip-line per row of plants $\left(\mathrm{GO}_{1 \mathrm{~L}}\right)$; two drip-lines per row of plants $\left(\mathrm{GO}_{2 \mathrm{~L}}\right)$; furrow (SU); microsprinkler below plant canopy $\left(\mathrm{MI}_{\text {sub }}\right.$ ); microsprinkler above plant canopy ( $\left.\mathrm{MI}_{\text {alta }}\right)$; and conventional overhead sprinkler (AS). Irrigation by drip systems $\mathrm{GO}_{1 \mathrm{~L}}$ and $\mathrm{GO}_{2 \mathrm{~L}}$ was carried out when soil water tensions reached 15-30 kPa (high moisture), while for SU the trigger soil tension was 30-60 $\mathrm{kPa}$ (moderate moisture). All other systems were conducted at both soil water tension ranges. Soil moisture levels were chosen based on preliminary tests, within working range adequate for economical fruit yield. One further treatment, aimed to exam the effect of organic mulch on the water dynamics and the efficiency of inoculum dispersal, was added with overhead sprinkler, high soil moisture and the soil covered by grass-straw mulch ( $\left.\mathrm{AS}_{\text {palha }}\right)$.

The experimental design was in randomized blocks, with 10 treatments and three replicates. Each experimental plot, with a total area of $50.0 \mathrm{~m}^{2}$, was made up of five rows of plants, each $10.0 \mathrm{~m}$ in length, totaling 100 plants. Borders of forage sorghum (Sorghum bicolor) and sunn hemp (Crotalaria juncea) were established around the experimental blocks, to increase the biological diversity, and as windbreaks. Additionally, the contour lines running alongside the experiment were planted with Mexican sunflower (Tithonia diversifolia) and elephant grass (Pennisettum purpureum).

Pre-planting fertilization was carried out with 2,500 $\mathrm{g}$ of organic compost (1.5\% of $\mathrm{N}, 4.0 \%$ of $\mathrm{P}_{2} \mathrm{O}_{5} ; 2.0 \%$ of $\mathrm{K}_{2} \mathrm{O} ; 6.3 \%$ of $\mathrm{Ca} ; 1.0 \%$ of $\mathrm{Mg} ; 0.7 \%$ of S; $0.02 \%$ of $\mathrm{Zn} ; 0.02 \%$ of $\mathrm{Cu} ; 0.07 \%$ of $\mathrm{Mn}$ and $0.01 \%$ of B) and $250 \mathrm{~g}$ of magnesium thermophosphate $(17 \%$ of $\mathrm{P}_{2} \mathrm{O}_{5} ; 7 \% \mathrm{Mg} ; 20 \% \mathrm{Ca}$ ) per linear meter.

Thirty day-old seedlings of cv. Pérola (Santa Cruz group), were transplanted in the first week of May 2011. The single 
row system was adopted, with a space of $1.0 \mathrm{~m}$ between plant rows and 0.50 $\mathrm{m}$ between plants. The plants were vertically staked using tape and trained with one stick per plant. Removal of shoots was carried out once a week, and weeding every two weeks. At 40, 70 and 100 days after transplanting, cover fertilization was applied, with $50 \mathrm{~g}$ per plant of anaerobic bokashi $(2.4 \%$ of $\mathrm{N}$, $5.8 \%$ of $\mathrm{P}_{2} \mathrm{O}_{5} ; 2.6 \%$ of $\mathrm{K}_{2} \mathrm{O} ; 7.5 \%$ of Ca; $2.3 \%$ of $\mathrm{Mg}$ ).

Spraying was carried out twice with Bordeaux mixture, at a concentration of $0.5 \%$, during the first 30 days after transplanting, and four more times, at a concentration of $2.0 \%$, after this period, mainly to prevent attack by Phytophthora infestans. While the experiment was underway, five sprays were applied with emulsible neem oil (2 $\mathrm{mL} / \mathrm{L}$ of water) and three with Bacillus thuringiensis subsp. kurstaki $(1.5 \mathrm{~mL} / \mathrm{L})$, both of which are natural insecticides registered in Brazil for use in organic agriculture. Only trace incidence of late blight was recorded at these conditions, and did not affect Septoria epidemics.

In the drip-irrigated experimental plots there were drip tubes with openings spaced $0.20 \mathrm{~m}$ apart, working pressure of $1.0 \mathrm{kgf} \mathrm{cm}^{-2}$ and flow of $1.4 \mathrm{~L} \mathrm{~h}^{-1}$. The drip lines were at first positioned at about $0.05 \mathrm{~m}$ from the row of plants and later at $0.15 \mathrm{~m}$. In the furrowirrigated treatment, water distribution was done with PVC tubes, and one furrow, with a slope of $0.5 \%$, was used per plant row. Control of the volume of water applied in each plot was done with a hydrometer and a tap at the entrance of each furrow. Diffusion-type microsprinklers, with water application directed downwards, an opening of 1.4 $\mathrm{mm}$, pressure of $100 \mathrm{kPa}$, triangular spacing of $1.0 \times 1.0 \mathrm{~m}$ and application intensity of $70.0 \mathrm{~mm} \mathrm{~h}^{-1}$ were used in the treatments irrigated by 'below-canopy' microsprinklers. In this configuration, the microsprinklers watered $100 \%$ of the soil surface and only the first $0.25 \mathrm{~m}$ of the plant height. For the 'above-canopy' microsprinkler irrigation, ballerina microsprinklers were used, with water coming from above, opening of $1.4 \mathrm{~mm}$, pressure of $150 \mathrm{kPa}$, spaced at $2.0 \times 2.0$ $\mathrm{m}$ and application intensity of 16.5 $\mathrm{mm} \mathrm{h}^{-1}$, with $100 \%$ of the area being watered. 'Above-' and 'below-canopy' irrigation are innovative methods that have been studied as to their effect to reduce powdery mildew levels in the Brazilian Mid-West (Lage, 2012). In the plots irrigated by conventional sprinkling above the plant canopy, impact sprinklers were used, with openings of $5 \times 8 \mathrm{~mm}$, spaced at $18 \times 12$ $\mathrm{m}$, working pressure of $250 \mathrm{kPa}$ and application intensity of $23.5 \mathrm{~mm} \mathrm{~h}^{-1}$. The sprinklers were first installed at a height of $0.4 \mathrm{~m}$ and later moved up to $1.9 \mathrm{~m}$, always above the tomato plant canopy.

The size of the water-drops in the sprinkler and microsprinkler systems was determined qualitatively, based on the degree of the jet spray $\left(\mathrm{G}_{\mathrm{d}}\right)$, as proposed by Raposo (1994), using the expression $\mathrm{G}_{\mathrm{d}}=0.1 \mathrm{P}_{\mathrm{S}} / \mathrm{d}$, in which $\mathrm{P}_{\mathrm{s}}$ is the working pressure of the sprinkler $(\mathrm{kPa})$ and " $\mathrm{d}$ " the diameter of the largest opening (mm). Based on the value of $\mathrm{G}_{\mathrm{d}}$, the following size classes were established: very large $(<3)$, large (3$4)$, medium (4-5), small (5-6) and very small $(>6)$. Thus, the drops generated in both microsprinkler systems were 'very small', while those applied by conventional sprinkler were 'large'.

The irrigations in each treatment were carried out whenever the water tension in the soil, evaluated at between $40 \%$ and $50 \%$ of the effective root depth, reached the pre-established trigger tension, i.e., 15-30 kPa (high moisture) or $30-60 \mathrm{kPa}$ (moderate moisture). The lowest trigger tensions, within each management strategy, were considered during the fruiting season, which is most sensitive to soil water shortage (Marouelli et al., 2011a). Tension was monitored by tensiometers installed in each of the experimental plots. The amount of water applied by irrigation aimed to return the soil to its field capacity at the effective root depth (Marouelli et al., 2011c).

Evaluations of severity of septoria leaf spot were carried out each week in the period between 50 and 105 days after transplant, starting at the onset of visual disease symptoms. After 105 days, incidence of powdery mildew (Leveillula taurica) in some treatments risked masking disease ratings and septoria leaf spot measurements were discontinued. Evaluations were carried out on 14 plants located in the central row of each experimental plot. For this, the diagrammatic scale of Boff et al. (1991) was modified, which had been developed originally for severity of tomato gray leaf spot caused by Stemphylium solani. Grades of 1, 2, 3, 4, 5, 6, 7 and 8 were attributed to the plants, corresponding to $1,2,4,8,16$, 32,64 and $100 \%$ of symptomatic leaves, respectively. Intermediate values were rounded to the closest grade.

Using the severity grades attributed throughout the epidemic cycles, severity was determined at half way through the time course of the epidemic $\left(\mathrm{Y}_{s_{0}}\right)$, 77 days after transplanting, at the end of the epidemic ( $\left.\mathrm{Y}_{\max }\right), 105$ days after transplanting, and the area under the disease progress curve was calculated (AUDPC), as proposed by Shaner \& Finney (1977). To analyze the temporal progress of the epidemic, the severity data were adjusted by linear regression to the Logistic and to the Gompertz models (Madden et al., 2007). The latter was chosen due to its best fit to the severity data, according to the conformation of the disease curves, the highest values of the adjusted coefficient of determination $\left(\mathrm{R}^{* 2}\right)$ and the independence and homogeneity of residues (Madden et al., 2007). Using the adjusted regression model, the rates of disease progress (r) were estimated for each treatment.

In addition to the severity of septoria leaf spot, evaluations were made of total fruit yield, total number of irrigations carried out and total amounts of water applied in each treatment. Fruits were harvested each week at the mature green stage.

Microclimate in each treatment was monitored by air temperature, relative humidity and leaf wetting sensors, installed along the line of plants, at $0.30 \mathrm{~m}$ from the soil surface, in the center of each plot of one experimental block. The data were stored every $30 \mathrm{~min}$ in automatic dataloggers. At 60 days, the sensors were raised to a height of $0.60 \mathrm{~m}$, following the development of the plants, and were 
kept at that height until the end of the experiment. Precipitation was measured by a rain gauge of the Ville de Paris type, using the effective precipitation as recommended (Marouelli et al., 2011c).

The data for $\mathrm{Y}_{50}, \mathrm{Y}_{\max }$, AUDPC, total fruit yield and rotten fruit were evaluated for normality and for homogeneity of variance. Later, they were submitted to analysis of variance and test for separation of means (Tukey, 5\%). Estimates of the rates of disease progress (r) among the treatments were compared by means of the confidence interval at 95\% of probability (Diniz et al., 2006, Madden et al., 2007).

\section{RESULTS AND DISCUSSION}

Depending on the treatment, 31 to 61 irrigations were carried out and the total depth of water ranged from $458 \mathrm{~mm}$ to $889 \mathrm{~mm}$ (Table 1). The smallest depths of water were applied on treatments $\mathrm{GO}_{1 \mathrm{~L}}$ and $\mathrm{GO}_{2 \mathrm{~L}}$, mainly because the drip system wets only part of the surface of the ground, which reduces loss by evaporation. As only part of the surface is watered the volume of water stored in the soil is lower and the watering needs to take place more frequently (Marouelli et al., 2011c). The greatest depth of irrigation was applied in the furrow treatment, as a consequence of its lower efficiency, which presents a significant loss of water by deep percolation. Relative to the soil moisture levels, larger depths of water were applied to high moisture treatments. According to Marouelli et al. (2011c), the higher the soil moisture, the greater is the crop's evapo-transpiration and, as a consequence, the greater the total depth of water applied and the higher the number of irrigations.

The complete effects of the irrigation treatments on the severity of septoria leaf spot can be seen in the disease progress curves (Figure 1). Severity at halfway through the time course of the epidemic $\left(\mathrm{Y}_{50}\right)$ was significantly greater in the treatments irrigated by conventional sprinkler (AS and $\mathrm{AS}_{\text {palha }}$ ) than in the others (Table 2). Among these, treatment AS with high soil moisture presented the highest $\mathrm{Y}_{50}(15.4 \%)$, followed by AS

Table 1. Total depth ( $\mathrm{mm}$ ), number of events and average frequency of irrigation throughout the tomato development cycle, according to the irrigation system and soil water level (lâmina total $(\mathrm{mm})$, número de eventos e frequência média de irrigação ao longo do ciclo de desenvolvimento do tomateiro, conforme o sistema de irrigação e o nível de umidade do solo). Brasília, Embrapa Hortaliças, 2011.

\begin{tabular}{llccc}
\hline System $^{\mathbf{1}}$ & $\begin{array}{c}\text { Moisture } \\
\text { level }\end{array}$ & $\begin{array}{c}\text { Depth } \\
(\mathbf{m m})\end{array}$ & $\begin{array}{c}\text { Number of } \\
\text { irrigations }\end{array}$ & $\begin{array}{c}\text { Frequency } \\
\text { (days) }\end{array}$ \\
\hline $\mathrm{GO}_{1 \mathrm{~L}}$ & High & 458 & 60 & 2.6 \\
$\mathrm{GO}_{2 \mathrm{~L}}$ & High & 505 & 61 & 2.5 \\
$\mathrm{SU}$ & Moderate & 889 & 33 & 4.7 \\
$\mathrm{MI}_{\text {sub }}$ & High & 715 & 45 & 3.3 \\
$\mathrm{MI}_{\text {sub }}$ & Moderate & 691 & 33 & 4.7 \\
$\mathrm{MI}_{\text {alta }}$ & High & 760 & 46 & 3.3 \\
$\mathrm{MI}_{\text {alta }}$ & Moderate & 730 & 36 & 4.3 \\
$\mathrm{AS}$ & High & 741 & 40 & 3.9 \\
$\mathrm{AS}$ & Moderate & 684 & 31 & 5.0 \\
$\mathrm{AS}_{\text {palha }}$ & High & 690 & 31 & 5.0 \\
\hline
\end{tabular}

${ }^{1} \mathrm{GO}_{1 \mathrm{~L}=}$ one drip-line per row of plants; $\mathrm{GO}_{2 \mathrm{~L}=}$ two drip-lines per row of plants; $\mathrm{SU}=$ furrow irrigation; $\mathrm{MI}_{\text {sub }}$ microsprinkler below canopy; $\mathrm{MI}_{\text {alta }}$ microsprinkler above canopy; $\mathrm{AS}=$ overhead sprinkler; $\mathrm{AS}_{\text {palha }}$ overhead sprinkler with straw mulch $\left(\mathrm{GO}_{1 \mathrm{~L}=}\right.$ gotejo em uma linha por fileira de plantas; $\mathrm{GO}_{2 \mathrm{~L}=}$ gotejo em duas linhas; $\mathrm{SU}=$ sulco; $\mathrm{MI}_{\text {sub= }}$ microaspersão subcopa; $\mathrm{MI}_{\text {alta }}$ microaspersão acima da dossel; $\mathrm{AS}=$ aspersão convencional; $\mathrm{AS}_{\text {palha }}$ aspersão convencional em solo coberto com palhada).

with moderate moisture $(11.7 \%)$ and $\operatorname{AS}_{\text {palha }}(8.5 \%)$. There was no significant difference in disease intensity among the drip-irrigation treatments, furrow or microsprinkler at halfway through the epidemic, irrespective of the configuration of the system and water management strategy ( $\mathrm{Y}_{50}$ between 2.1 and $3.9 \%$, Table 2 ).

Greater severity at the end of epidemic $\left(\mathrm{Y}_{\max }\right)$ was also observed in the treatments with conventional sprinkler (Table 2). The highest value for $\mathrm{Y}_{\mathrm{m}, \mathrm{w}}$ was seen in treatment AS with high moisture $(35.1 \%)$, significantly higher than in $\operatorname{AS}_{\text {palha }}(30.5 \%)$, which was not separate from AS with moderate moisture (32.8\%). Lower values for $\mathrm{Y}_{\max }$ were seen in the treatments irrigated by the systems that did not wet the aerial plant parts $\left(\mathrm{GO}_{1 \mathrm{~L}}, \mathrm{GO}_{2 \mathrm{~L}}\right.$ and $\left.\mathrm{SU}\right)$, without significant differences among them (mean of $3.9 \%$ ). Treatments irrigated by microsprinkler presented $\mathrm{Y}_{\max }$ between $6.1 \%$ and $10.3 \%$, and significant differences were not observed when the microsprinklers were placed at $0.25 \mathrm{~m}$ from the soil $\left(\mathrm{MI}_{\text {sub }}\right)$ or above plant canopy $\left(\mathrm{MI}_{\text {alta }}\right)$. It was noted, however, that the final disease severity was highest in the most frequently irrigated treatments, i.e. those with high soil moisture (Table 2).

The AUDPC data ratified the epidemic severities that had been observed in the analysis of variables $\mathrm{Y}_{50}$ and $\mathrm{Y}_{\max }$. AUCPDs clearly showed the cumulative hampering effect of straw mulch on the severity of septoria leaf spot epidemics when the crop is sprinkler-irrigated (Table 2). The AUDPC in the treatment $\mathrm{AS}_{\text {palha }}$ was significantly lower than in the other AS treatments, either at the same soil water level ( $\mathrm{AS}_{\text {palha }} v s$. AS with high moisture) or at identical irrigation frequencies $\left(\mathrm{AS}_{\text {palha }}\right.$ vs. AS with moderate moisture).

The rate of disease progress (r) in the treatments irrigated by conventional sprinkler was on average $146 \%$ greater than in those irrigated by drip and by furrow. It was $78 \%$ greater than in those irrigated by microsprinkler, but no significant effect of irrigation level on the rate of disease progress was noted (Table 2). It was seen that the greatest surge in disease progress in the treatments irrigated by conventional sprinkler took place from 70 days after seedlings have been transplanted, while 
Table 2. Severity of septoria leaf spot at 77 days $\left(\mathrm{Y}_{50}\right)$ and 105 days $\left(\mathrm{Y}_{\max }\right)$ after tomato seedling transplant, area under the disease progress curve (AUDPC), disease progress rate (r), estimated by the Gompertz model, and total fruit yield (PT), according to the irrigation system and soil water level (severidade da mancha de septória aos 77 dias $\left(\mathrm{Y}_{50}\right)$ e 105 dias $\left(\mathrm{Y}_{\max }\right)$ após o transplantio de tomate, área sob a curva de progresso de doença (AUDPC), taxa de progresso da doença (r), estimada pelo modelo de Gompertz e produção total de frutos (PT), conforme o sistema de irrigação e nível de umidade do solo). Brasília, Embrapa Hortaliças, 2011.

\begin{tabular}{llccccc}
\hline System $^{1}$ & Moisture level & $\mathbf{Y}_{\mathbf{5 0}}{ }^{2(\% \text { leaf area) }}$ & $\mathbf{Y}_{\text {max }}{ }^{2 \text { (\% leaf area) }}$ & AUDPC $^{2 \text { (severity-days) }}$ & $\mathbf{r}^{2}$ & PT (t/ha) $^{2}$ \\
\hline $\mathrm{GO}_{1 \mathrm{~L}}$ & High & $2.1 \mathrm{~d}$ & $3.7 \mathrm{e}$ & $122 \mathrm{~d}$ & $0.013 \mathrm{c}$ & $114.6 \mathrm{bc}$ \\
$\mathrm{GO}_{2 \mathrm{~L}}$ & High & $2.2 \mathrm{~d}$ & $3.8 \mathrm{e}$ & $125 \mathrm{~d}$ & $0.013 \mathrm{c}$ & $121.7 \mathrm{bc}$ \\
$\mathrm{SU}^{2}$ & Moderate & $2.5 \mathrm{~d}$ & $4.2 \mathrm{de}$ & $141 \mathrm{~d}$ & $0.014 \mathrm{c}$ & $137.4 \mathrm{a}$ \\
$\mathrm{MI}_{\text {sub }}$ & High & $3.9 \mathrm{~d}$ & $10.3 \mathrm{c}$ & $263 \mathrm{c}$ & $0.020 \mathrm{~b}$ & $133.5 \mathrm{ab}$ \\
$\mathrm{MI}_{\text {sub }}$ & Moderate & $2.7 \mathrm{~d}$ & $6.1 \mathrm{de}$ & $187 \mathrm{~cd}$ & $0.016 \mathrm{bc}$ & $137.6 \mathrm{a}$ \\
$\mathrm{MI}_{\text {alta }}$ & High & $3.3 \mathrm{~d}$ & $10.2 \mathrm{c}$ & $248 \mathrm{c}$ & $0.020 \mathrm{~b}$ & $129.4 \mathrm{ab}$ \\
$\mathrm{MI}_{\text {alta }}$ & Moderate & $2.3 \mathrm{~d}$ & $7.0 \mathrm{~d}$ & $178 \mathrm{~cd}$ & $0.017 \mathrm{bc}$ & $136.5 \mathrm{a}$ \\
$\mathrm{AS}$ & High & $15.4 \mathrm{a}$ & $35.1 \mathrm{a}$ & $836 \mathrm{a}$ & $0.034 \mathrm{a}$ & $109.8 \mathrm{c}$ \\
$\mathrm{AS}$ & Moderate & $11.7 \mathrm{~b}$ & $32.8 \mathrm{ab}$ & $830 \mathrm{a}$ & $0.033 \mathrm{a}$ & $128.3 \mathrm{ab}$ \\
$\mathrm{AS}$ & & $8.5 \mathrm{c}$ & $30.5 \mathrm{~b}$ & $608 \mathrm{~b}$ & $0.030 \mathrm{a}$ & $117.3 \mathrm{bc}$ \\
\hline $\mathrm{CV}(\%)$ & High & 16.6 & 7.2 & 8.5 & & 5.9
\end{tabular}

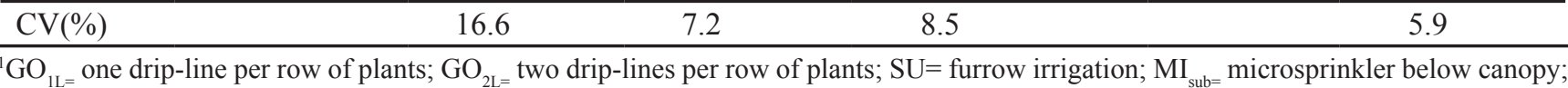
$\mathrm{MI}_{\text {alta }}$ microsprinkler above canopy; $\mathrm{AS}=$ overhead sprinkler; $\mathrm{AS}_{\text {palha }}$ overhead sprinkler with straw mulch $\left[\mathrm{GO}_{1 \mathrm{~L}=}\right.$ gotejo em uma linha por fileira de plantas; $\mathrm{GO}_{2 \mathrm{~L}=}$ gotejo em duas linhas; $\mathrm{SU}=$ sulco; $\mathrm{MI}_{\text {sub= }}^{\text {palta- }}$ microaspersão sub-copa; $\mathrm{MI}_{\text {alta= }}$ microaspersão acima da dossel; $\mathrm{AS}=$ aspersão convencional; $\mathrm{AS}_{\text {palha= }}$ aspersão convencional em solo coberto com palhada). ${ }^{2}$ means followed by the same letter do not differ by Tukey's test, 5\% (médias seguidas da mesma letra não diferem entre si, Tukey, $5 \%$ )].
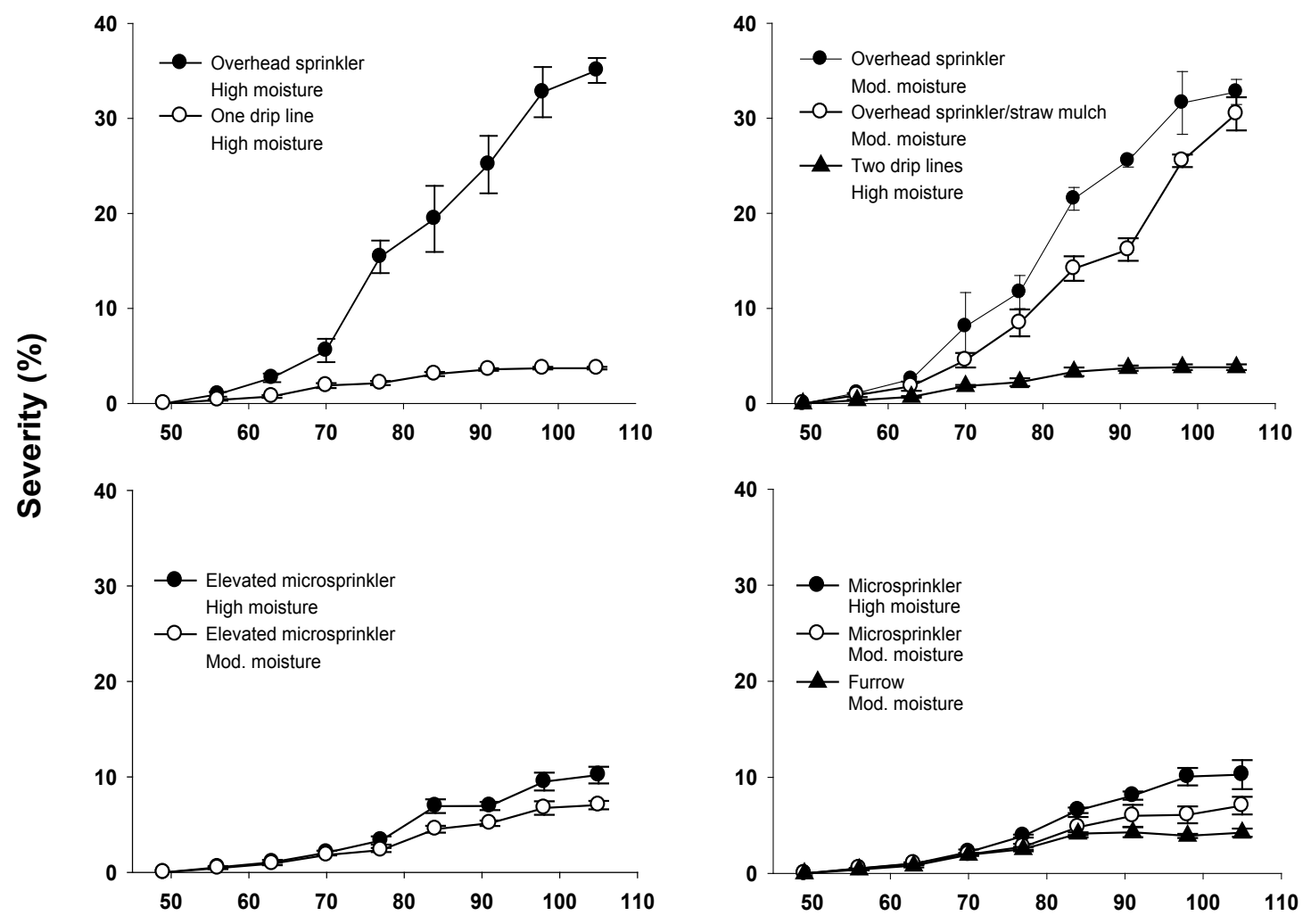

\section{Days after Planting}

Figure 1. Septoria leaf spot progress curves in the tomato crop, according to the irrigation system and the level of soil water (curvas de progresso da severidade da mancha de septória em tomate, de acordo com sistema de irrigação e nível de umidade do solo). Brasília, Embrapa Hortaliças, 2011. 


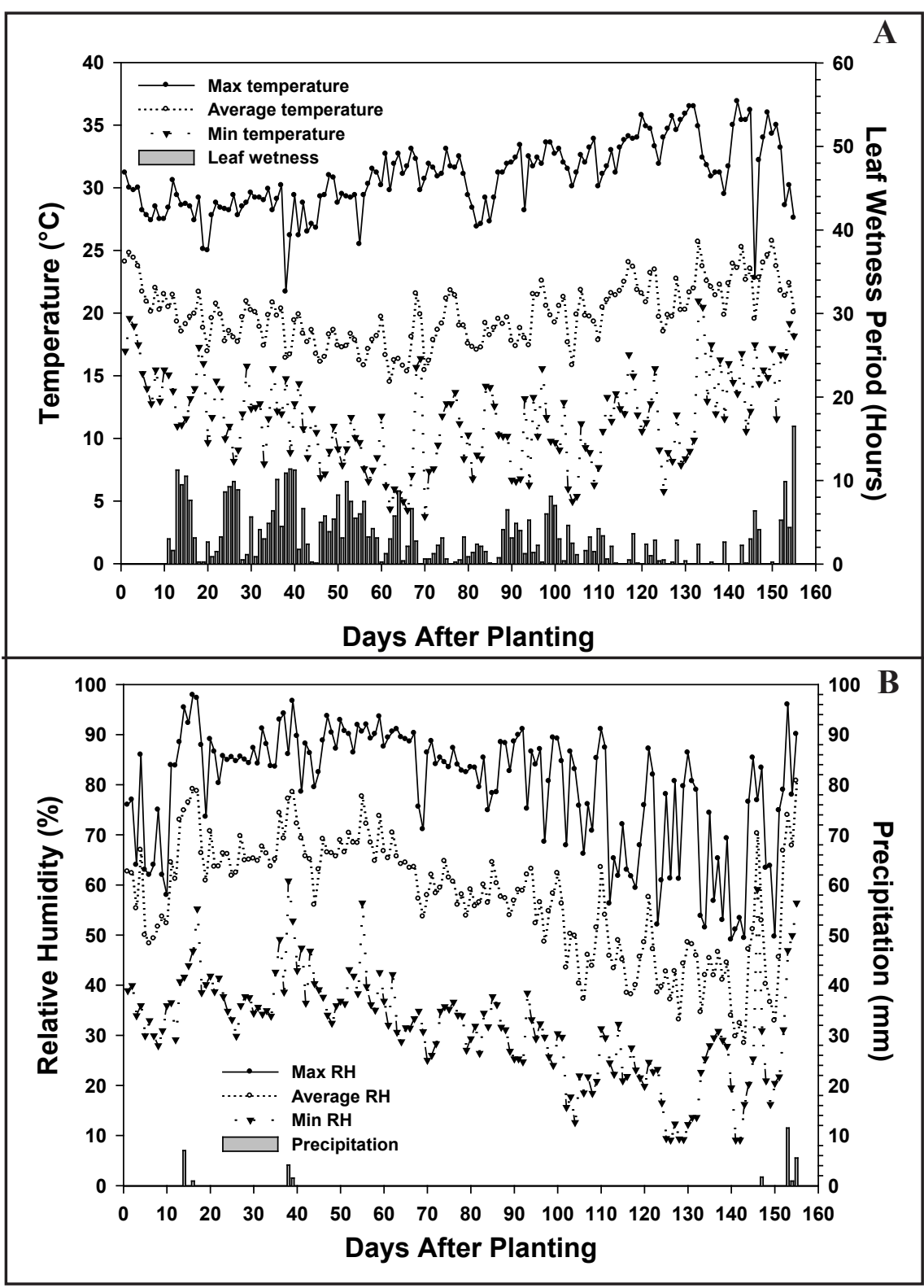

Figure 2. Climatic variables recorded in the overhead sprinkler treatment with high soil moisture during the course of the experiment. A) Leaf wetness and average, maximum and minimum daily temperatures. B) Average, maximum and minimum relative air humidity daily and precipitation (variáveis climáticas registradas no tratamento com irrigação por aspersão e alto nível de umidade do solo durante o experimento. A) Molhamento foliar e temperaturas médias, máximas e mínimas. B) Umidades relativas, médias, máximas e mínimas e precipitação). Brasília, Embrapa Hortaliças, 2011.

severity in drip and furrow remained almost constant, and at very low levels (Figure 1).

Although irrigation frequency, a function of soil water levels, did not significantly affect $\mathrm{Y}_{50}$ in conventional sprinkler or microsprinkler treatments, the data for $\mathrm{Y}_{\max }$ indicate that adoption of longer intervals between irrigations may be a useful strategy in reducing the rate of progress and final severity of septoria humidity and in the duration of leaf wetting within the tomato leaf canopy, which would explain the differences observed in the septoria leaf spot epidemics in each treatment. This is illustrated by the micro-climatic data in two contrasting treatments, furrow and sprinkler with high moisture (Figures 2 and 3). Total precipitation in the period during which the experiment was conducted was only $17 \mathrm{~mm}$. Although climatic conditions are generally dry, especially during the daytime, relative air humidity frequently reached above $80 \%$ at night, with formation of dew (leaf wetness) in all the treatments. The duration of leaf wetness underwent little influence of the experimental treatments, and periods of more than $5 \mathrm{~h}$ of leaf wetness were often noted in all treatments. Extremes of 10 to $12 \mathrm{~h}$ of leaf wetting were registered occasionally. It should be emphasized that the irrigations were carried out between $9 \mathrm{~h}$ and $15 \mathrm{~h}$, and thus the water applied by the systems that promote leaf wetting probably did not increase leaf wetness significantly.

For Septoria tritici infection to occur in wheat (Hess \& Shaner, 1987) and Septoria apiicola in celery (Sheridan, 1968), 12 to $15 \mathrm{~h}$ of leaf wetting are necessary. In the infection process of $S$. lycopersici, periods of longer than $16 \mathrm{~h}$ of free water on the leaf are considered optimal, as they favor maximum penetration by the fungus. However, in conditions with no leaf wetting or short wetness periods the infection may occur, although less frequently (Elmer \& Ferrandino, 1995).

Considering this, the significant differences in disease severity noted among the different irrigation treatments can be linked primarily to the form in which the water is applied to the plants and to the biology of S. lycopersici. As the fungus develops, conidia formed in pycnidia are released in hyaline cirrus clouds, kept together by a mucilaginous matrix (MacNeill, 1950). The mere action of wind is not efficient in disseminating conidia agglutinated into the matrix. According to Lopes et al. (2005), the dispersal and dissemination of conidia in this type of formation occurs mainly by the impact of water 


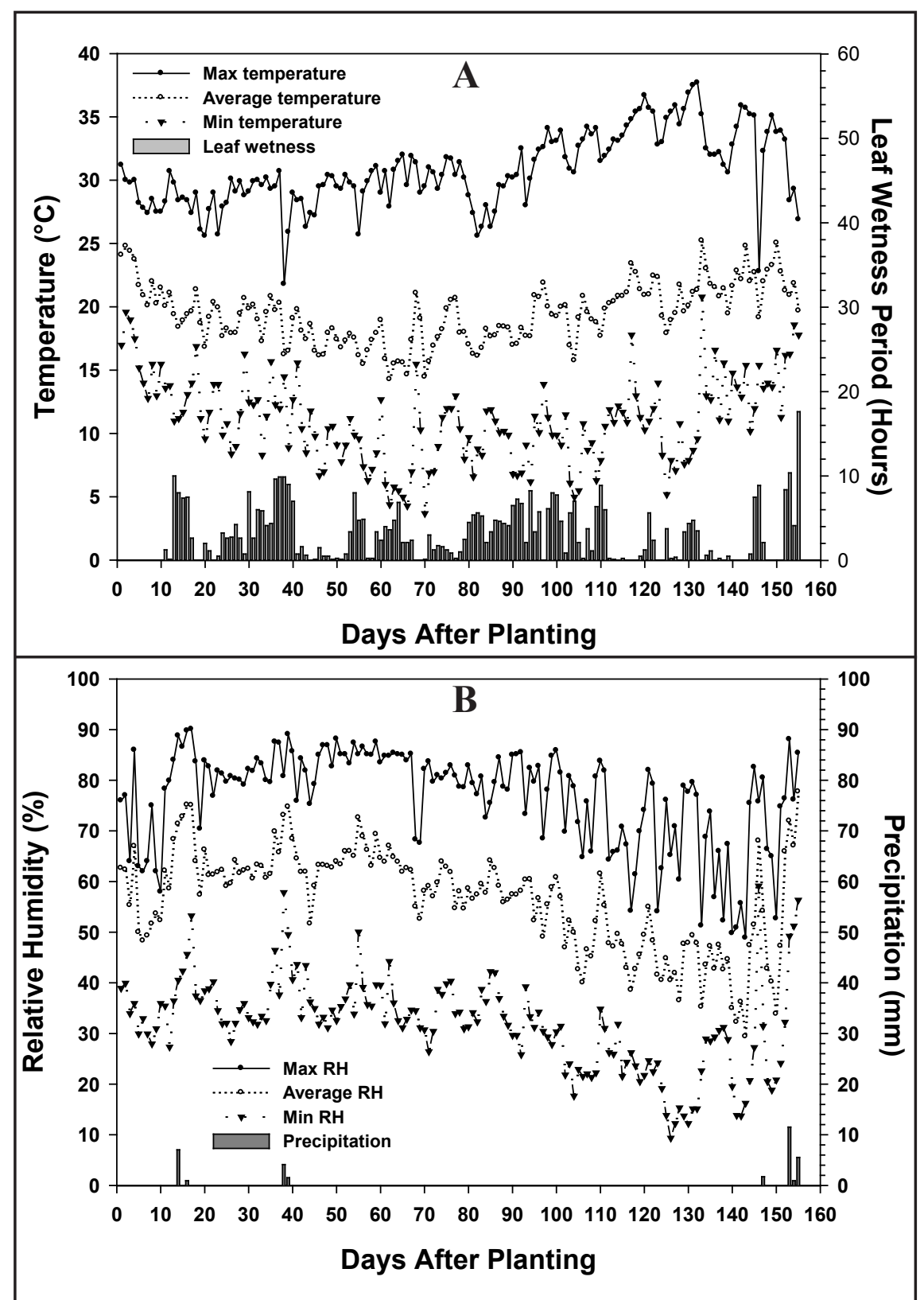

Figure 3. Climatic variables recorded in the furrow irrigated treatment during the course of the experiment. A) Leaf wetness and average, maximum and minimum daily temperatures. B) Average, maximum and minimum daily relative air humidity and precipitation (variáveis climáticas registradas no tratamento com irrigação por sulco durante o experimento. A) Molhamento foliar e temperaturas médias, máximas e mínimas. B) Umidades relativas, médias, máximas e mínimas e precipitação). Brasília, Embrapa Hortaliças, 2011.

drops on the plants. A similar effect was observed in another pathosystem with a causal agent that also has conidia surrounded by a gelatinous matrix, strawberry anthracnose, caused by Colletotrichum acutatum (Coelho et al., 2008).

According to Parker et al. (1995), conidia of $S$. lycopersici can be taken by splashes of water to a distance of more than $1.8 \mathrm{~m}$ away from the inoculum of data. However, the most efficient dissemination of the inocula and the infection of the host tissues, observed in treatments MI and AS, can be ascribed the impact of the drops of water on the tomato leaves, necessary for the effective dissemination of the pathogen, coupled together with the fact that on these treatments there was also enough leaf wetness for the conidia that reached the phyloplane to start the infectious process. Of course, the larger drops in the AS treatments were determinant in providing optimal conditions for the most severe epidemics.

In the treatments irrigated by conventional sprinkler, the energy released from the impact of the drops on the plant surface is much greater than in the treatments irrigated by microsprinkler, with very small drops. According to Gregory et al. (1959) and Hirst \& Stedman (1963), drops with a greater diameter divide into smaller drops when they reach the plants, carrying within them conidia present in the lesions that received the impact of the drops. Consequently, the largest drops of water sprinkled on the plants in the conventional sprinkler treatments had a greater capacity to dislodge the conidia from the cirrus and were more efficient in spreading them within the same plant and among plants; this was notably more than with the very small drops applied on the plants irrigated by microsprinkler. Similarly, Coelho et al. (2008) verified that there was a significant reduction in the severity of anthracnose, caused by Colletotrichum acutatum, in strawberry plants irrigated by microsprinkler, compared to conventional sprinkler.

In addition, the greater severity in the treatments with high soil moisture is probably due to the greater frequency and the larger amount of irrigation applied. According to Gregory et al. (1959), these factors provide greater opportunities of dislodging and carrying the conidia present in the lesions.

The effects of choice of irrigation system and of water regimes on septoria leaf spot, though demonstrated here to be very large, were somewhat expected. On the other hand, the effect of organic mulch may be regarded as a novelty. Treatment $\mathrm{AS}_{\text {palha }}$, even irrigated with 
amounts and frequencies close to treatment AS with high moisture, presented a lower severity of septoria leaf spot $\left(\mathrm{Y}_{50}\right.$ and AUDPC). This is probably due to a delaying effect of the straw mulch on the dissemination of $S$. lycopersici. This has been observed in other pathosystems, when straw served as a physical barrier between the primary inoculum in the soil and host organs in rainfed or sprinkler irrigated crops (e.g. Freitas et al., 2002; Napoleão et al., 2005). Thus, the lower severity of septoria leaf spot in treatment $\mathrm{AS}_{\text {palha }}$ may be associated not only with the reduced water splashes and with the energy absorption that the drops undergo when they reach the mulch, as it happens with conidia of C. acutatum (Coelho et al., 2008), but also with the putative reduction of the efficiency of the primary inoculum present in the area, when the straw acted as a physical barrier to the conidia to reach the plant. Thus, although the irrigation system is by far the most important factor in the septoria leaf spot epidemic, the use of soil cover with straw mulch may help in managing the disease when irrigation is done by sprinkler.

In the drip and furrow treatments, water splashes and leaf wetting are lacking and, without rain, the dissemination of the disease was almost exclusively by means of contact with workers, farming tools and insects moving among leaves (Kurozawa \& Pavan, 2005). The low disease severities in these systems may also be associated to the fact that these irrigation systems do not wet and wash the leaves, so organic defense products remain and act for longer on the plant surfaces (Hunsche et al., 2007; Fife \& Nokes, 2002).

There was no effect of the treatments on the duration of the tomato plant's development cycle, which was 154 days and summed nine harvests in all the treatments. However, the total fruit yield was significantly affected (Table 2). The highest productivities were observed in treatments irrigated by sprinkler with moderate moisture and by furrow, and these two did not differ $(\mathrm{p}<0.05)$ from those irrigated by microsprinkler with high moisture and by conventional sprinkler with moderate moisture. The lowest productivity occurred in the AS treatment with high moisture, which did not differ from the drip treatments.

With the exception of the drip treatments, fruit productivity was negatively related to the severity of septoria leaf spot. As a rule, higher yields were observed in treatments with lower disease severities, i.e., in those irrigated by microsprinkler with less frequent irrigations, and by furrow. According to Marouelli et al. (2011b), the reduction in the productive potential of the tomato plant irrigated by drip systems is associated with the lower volume of soil exploited by the roots, because only part of the soil is watered. It is also linked to the fact that nutrients are made available by the soil more slowly and gradually in organic systems, due to the use of fertilizers with low solubility, which limits the absorption of nutrients and hampers plant development.

Overall, results presented here confirm that the conventional sprinkler irrigation system favored more severe septoria leaf spot epidemics, while the drip and furrow systems were seen to be efficient, hindering dissemination of the pathogen. The size of the drops of water splashed on the plants had a strong effect on disease severity, which became more severe as drop size increased. Finally, increasing the interval of time between irrigations by sprinkler, and the adoption of organic soil mulch delayed disease onset may act synergistically to further reduce disease levels. All these measures may be combined and recommended for the management of septoria leaf spot, either in organic or conventional tomato crops.

\section{ACKNOWLEDGEMENTS}

The authors thank the Centro de Desenvolvimento Tecnológico da Agricultura Orgânica do Distrito Federal (CDTOrg-DF) and the Brazilian National Research Council (CNPq) for partial financial support during the study. WA Marouelli and AC Café-Filho are CNPq Research Fellows.

\section{REFERENCES}

BOFF P; ZAMBOLIM L; VALE FXR. 1991. Escalas para avaliação de severidade da mancha de estenfílio (Stemphylium solani) e da pinta preta (Alternaria solani) em tomateiro. Fitopatologia Brasileira 16: 280-283.

COELHO MVS; PALMA FR; CAFÉ-FILHO AC. 2008. Management of strawberry anthracnose by choice of irrigation system, mulching material and host resistance. International Journal of Pest Management 54: 347-354.

DINIZ LP; MAFFIA LA; DHINGRA OD; CASALI VWD; SANTOS RHS; MIZUBUTI ESG. 2006. Avaliação de produtos alternativos para o controle da requeima do tomateiro. Fitopatologia Brasileira 31: 171-179.

ELMER WH; FERRANDINO FJ. 1995. Influence of spore density, leaf age, temperature, and dew periods on Septoria leaf spot of tomato. Plant Disease 79: 287-290.

FERRANDINO FJ. 1993. Dispersive epidemic waves: I. Focus expansion within a linear planting. Phytopathology 83: 795-802.

FIFE JP; NOKES SE. 2002. Evaluation of the effect of rainfall intensity and duration on the persistence of chlorothalonil on processing tomato foliage. Crop Protection 21: 733-740.

FREITAS MA; CAFÉ-FILHO AC; NASSER LCB. 2002. Cultural practices and genetic resistance as factors affecting soybean stem canker and plant yield in the Cerrado. Fitopatologia Brasileira 27: 5-11.

GREGORY PH; GUTIIRIE E; BUNCE ME. 1959. Experiments on splash dispersal of fungus spores. Journal of General Microbiology 29: 328-354.

HESS DE; SHANER G. 1987. Effect of moisture on Septoria tritici blotch development on wheat in the field. Phytopathology 77:220-226.

HIRST JM; STEDMAN OJ. 1963. Dry liberation of fungus spores by rain drops. Journal of General Microbiology 33: 335-344.

HUNSCHE M; DAMEROW L; SCHMITZEIBERGER M; NOGA G. 2007. Mancozeb wash-off from apple seedlings by simulated rainfall as affected by drying time of fungicide deposit and rain characteristics. Crop Protection 26: 768-774.

JONES JB; JONES JP; STALL RE; ZITTER TA (eds). 1991. Compendium of tomato diseases. St. Paul: American Phytopathological Society, $73 p$.

KUROZAWA C; PAVAN MA. 2005. Doenças do tomateiro (Lycopersicon esculentum). In: KIMATI H; AMORIM L; REZENDE JAM; BERGAMIN FILHO A; CAMARGO LEA. Manual de fitopatologia: doenças das plantas cultivadas. 4. ed. São Paulo: Agronômica Ceres. p. 607-626.

LAGE DAC. 2012. Epidemias de oídio e requeima do tomateiro orgânico em diferentes sistemas de irrigação: quantificação e progresso temporal. Brasília: UnB. $105 \mathrm{p}$ (Tese doutorado).

LAGE DAC; MAROUELLI WA; CAFÉ-FILHO AC. 2011a. Tomato powdery mildew may be significantly reduced by choice and 
management of irrigation system in the Brazilian Midwest. Phytopathology 101: S97. (abstract).

LAGE DAC; CABRAL RN; MAROUELLI WA; CAFÉ-FILHO AC. 2011b. Métodos e manejo de irrigação para o controle de doenças no Brasil Central: Avanços para a cultura do tomateiro. In: GEAFIP-UFV. (org). Avanços e perspectivas no manejo de doenças de plantas. 1 ed. Viçosa, p. 91-108.

LOPES CA; REIS A; BOITEUX LS. 2005. Doenças fúngicas. In: LOPES CA; ÁVILA AC. (eds). Doenças do tomateiro. Brasília: Embrapa Hortaliças. p.17-51.

LOPES CA; MAROUELLI WA; CAFÉ-FILHO AC. 2006. Associação da irrigação com doenças de hortaliças. Revisão Anual de Patologia de Plantas 14: 151-179.

MACNEIL BH. 1950. Studies in Septoria lycopersici Speg. Canadian Journal of Research 28: 645-672.

MADDEN LV: HUGHES, G; BOSCH. 2007. The study of plant disease epidemics. Saint Paul: APS Press.

MAROUELLI WA; CARRIJO OA; SOUZA RB; SILVA WLC. 2011a. Irrigação e fertirrigação na cultura do tomate. In: SOUSA VF;
MAROUELLI WA; COELHO EF; PINTO JM; COELHO FILHO MA. (eds). Irrigação e fertirrigação em fruteiras e hortaliças. Brasília: Embrapa Informação Tecnológica. p. 739-769.

MAROUELLI WA; LOPES CA; SILVA WLC. 2005. Incidência de murcha-bacteriana em tomate para processamento industrial sob irrigação por gotejamento e aspersão. Horticultura Brasileira 23: 320-32.

MAROUELLI WA; MEDEIROS MA; SOUZA RF; RESENDE FV. 2011b. Produção de tomateiro orgânico irrigado por aspersão e gotejamento, em cultivo solteiro e consorciado com coentro. Horticultura Brasileira 29: 429-434.

MAROUELLI WA; OLIVEIRA AS; COELHO EF; NOGUEIRA LC; SOUSA, VF. 2011c. Manejo da água de irrigação. In: SOUSA VF; MAROUELLI WA; COELHO EF; PINTO JM; COELHO FILHO MA. Irrigação e fertirrigação em fruteiras e hortaliças. Brasília: Embrapa Informação Tecnológica. p. 157-232.

NAPOLEÃO RL; CAFÉ-FILHO AC; NASSER LCB; LOPES CA; SILVA HR. 2005. Intensidade do mofo-branco do feijoeiro em plantio convencional e direto sob diferentes lâminas d'água. Fitopatologia Brasileira 30: 374-379.

PARKER SK, GLEASON ML, NUTTER FW JUNIOR. 1995. Influence of rain events on spatial distribution of septoria leaf spot of tomato. Plant Disease 79: 148-152.

RAPOSO JR. 1994. A rega por aspersão. 2. ed. Lisboa: Livraria Clássica Editora. 358 p.

ROTEM J; PALTI J. 1969. Irrigation and plant diseases. Annual Review of Phytopathology 7: 267-288.

SCHALLENBERGER E; REBELO JA; MAUCH CR; TERNES M; PEGORARO RA. 2008. Comportamento de plantas de tomateiros no sistema orgânico de produção em abrigos de cultivo com telas antiinsetos. Revista de Ciências Agroveterinárias 7: 23-29.

SHANER G; FINNEY RE. 1977. The effect of nitrogen fertilization on the expression of slow-mildewing resistance in knox wheat. Phytopathology 67: 1051-1056.

SHERIDAN JE. 1968. Conditions for infection of celery by Septoria apiicola. Plant Disease Reporter 52: 142-145.

SOUZA JL. 2003. Tomateiro para mesa em sistema orgânico. Informe Agropecuário 24: 108-120. 